\title{
CULTURAL-GEOGRAPHIC DETERMINANTS OF JERUSALEM
}

\author{
JOVO MEDOJEVIĆ ${ }^{1^{*}}$ \\ ${ }^{1}$ Faculty of Natural Science and Mathematics, University of Priština, Kosovska Mitrovica, Serbia
}

\begin{abstract}
Culture and cultural phenomena are always in the focus of studying cultural geography. The study of Jerusalem from the aspect of supranational spread of culture is a special challenge. The cultural-geographical determinants of Jerusalem represent the features seen through the factors of time and space in which Jerusalem became and survived. The study of the morphology of cultural-geographical determinants in Jerusalem represents scientifically study of the relationship between man and his environment, the man's belief and application of perception of cultural-geographic determinants.
\end{abstract}

Keywords: Cultural-geography, Jerusalem, pilgrimage.

\section{INTRODUCTION}

The empirical determination of cultural-geographical determinants of Jerusalem was seen as a very complex cultural system of all three great monotheistic religions: Judaism, Christianity and Islam. By connecting all these three aspects, you can see what place Jerusalem has had in all the epochs of civilization since creation until the present day. The cultural and geographical determinants of Jerusalem construct an original and unique cultural pattern in the function of understanding of Jerusalem as a universal aspect of culture.

\section{MATERIAL AND METHODS}

Methodological research is based on explicitly-qualitative methods applied in the field of cultural geography. Sociogeographical methodology was used to understand the space of Jerusalem and it`s incorporation in geographical science. Also, the reflection method of historical research of representative examples of cultural and historical monuments of Jerusalem has a goal to indicate transcendental reflection of the God's existence according to the belief of Jews, Christians and Muslims. Methodology of sacral geography has for goal to point out the relation of culture and space, and to consider these relationships through the prism of religious traditions that always have a certain geographical component.

\section{THE COMPLEX OF THE CULTURAL SYSTEM OF JERUSALEM}

There are hundreds of names for God and Jerusalem. One of these names is Salim (Shalem), which was first read from a tile found in Syria five thousand years ago. And in the Holy Bible, Jerusalem has been mentioned as Salim, which signifies perfection. Jerusalem is located in the central part of the Judean hills surrounded by a desert that begins right behind the Mount of Olives. In its long history, Jerusalem hasn`t resemble a look of a western cities or the Mediterranean (Nastić, 1997).

The Jerusalem landscape is unique, it refers to soul and eyes as well. This outer world of Jerusalem obsess everyone with a multitude of phenomena, color, stone, architecture, churches, synagogues, mosques. On the site of today's old city of Jerusalem, it was a smaller panel, with a wide and flat Rock about 2 meters high, which served as an altar to the pagan god Baal. This Rock was chosen by God to become an altar. On that Rock, Cain killed Abel. On that same Rock, Abram offered to God his son, Isaac, as the sacrifice. On that Rock God has appeared to Abram. This place was the center of the Jerusalem Temple Mount, at this place there was the Rock - the Sanctuary of the Saints, which is now under the golden dome of the Omar mosque. The Temple Mount has become a sacred place for the Jews, Christians and Muslims. On the west side of the Temple Mount there is surviving remnant of the Solomon`s Temple, known as Western Wall which is the largest Jewish sanctuary. In Jerusalem, the Jews began to live according to divine laws of Moses or Mosaic Law.

The population of Jerusalem has been mixed since ancient times, so the city often changed name with the change of master: Jewish, Greek, Latin, and Arabic. Biblical name j.r.s.l.m. it is most similar to today's Hebrew pronunciation "Yerushalayim" (Ginsberg, 1956). The interpretation of the linguist is that this name represents the connection between the earthly and the heavenly. At the place where God had appeared to Abram, Solomon has built a temple for seven years and at the time that was the most perfect building that human eye has ever seen. The Jewish temple did not look like today's synagogues and churches in which faithful people gather to pray together. The Jerusalem Temple was God's house on earth, where only priests could enter. Solomon slaughtered 22,000 oxen and 120,000 sheep as a peace gift to God for the sanctification of his Temple (Nastić, 1997). 


\section{REFLECTIONS OF HISTORICAL-GEOGRAPHIC DETERMINANTS}

By the end of the 4th century BC Jerusalem became part of the Hellenistic world. Greek culture has become acceptable for many Jews who wanted to be like Greeks. They learned and spoke Greek, they took Greek names. In 37th year BC Rome "Herod the Great" was named as King of Jews. The Arabs worshiped Jerusalem. For them it was the Holy City which God blessed among their cities, Mecca and Medina. The Arabs called Jerusalem "Beit el Makdis" (Holy House). After the Muslim conquest of Jerusalem on the Temple Mount, they prepared pilgrimage site for 3000 pilgrims. At this place in 705 year, El Valid built the El Aqsa mosque (Bahat, 1980). Suleiman the Magnificent surrounded Jerusalem with the walls in 1542. These walls have been preserved till today and make a clear border between the sacred and the profane world. After Suleyman's death, the Pasha administrators began to fight among themselves, and the sole interest of Carigrad was tax revenue. Jerusalem was ruined, and there were less and less pilgrims in Jerusalem (Grindea, 1980). The four centuries of Ottoman rule in Jerusalem (from 1517 to 1917) was overwhelmed by severe torture and Turkish zulum. Somehow a Greek church was held, it was privileged by the Turks. In 1815 Jerusalem Holy Places were subject to political debate between the European nations. Disagreements over the Holy Places were one of the causes of the Crimean War (1854-1856). Order privileges are given to France in terms of Holy Places in Jerusalem and Bethlehem, as well as in regard to protectors of Latin Christians. Russia has protected the Greek Church. At that time, there were about 68,000 inhabitants in Jerusalem. The city was spread outside the walls of the Old Town towards the western and southern hills. Suez Canal, opened in 1869, regained strategic importance for the entire region. At the same time, the route between Jaffa and Jerusalem (in the length of about 80 kilometers) was repaird, and in 1892 the railroad passed through the Holy Land. Pilgrims arrived to pilgrimage. Russian emperors organized free pilgrimages to Jerusalem. Thus, the Russian mass pilgrimage began in 1847. About 20,000 Russians gathered for Easter in Jerusalem. They were placed for free in the large Russian complex in Jerusalem. It is assumed that in the 19th century Jerusalem was visited by about a million pilgrims from Europe. In England, for over forty years (1840-1880), over 1,500 travelogues were written about Jerusalem (Peters, 1985). Jerusalem was liberated from the Turkish occupation by the British at December 9th, 1917. British General Edmund Allenby, occupied Jerusalem without a bullet, he dismounted his horse at the Gate of Jaffa and walked on foot to Jerusalem. Eyewitnesses claimed that they had never seen before the British general so meekly as when he was entering in the Holy City of Jerusalem. After the First World War, the British ruled Palestine on the basis of the mandate system of the League of Nations. Britain was in control of Palestine for thirty years. The first British military governor in Jerusalem, Sir Ronald Storrs, in 1917, passed a law that the only building material that can be used in Jerusalem is a stone of amber colour. This law is still respected by the Jews and the Arabs. Jews, but not Muslims, until the 1967 were forbidden to enter in the Church of the Holy Sepulchre (Holy Grave) (Bostock, 1982). After the Second World War, in 1947. by the United Nations Resolution, Palestine was divided into Arab and Jewish states. The Arabs have never accepted this Resolution. On May 15th, 1948, the Israeli declaration of independence was declared. The Jordans tried to conquer Jerusalem, but after two weeks of fighting for each house, this attempt failed. Israeli military forces have established a corridor. The Jews kept control of the New City, and the Jordans stayed in the Old City of Jerusalem. It remains to be remembered that Jerusalem from 1948 to 1967 was divided by barbed wire. The Israeli-Jordanian truce, from 1949, guaranteed the free access of Jews to the Western Wall. However, the Jordans never complied with this arrangement. They forbid access to all sacred places to Jews, Muslims and Christians. Only Christians had access to the Holy Places for Christmas and Easter (Nastić, 1997). In the Sixday Israeli-Jordanian War, which began on June 5th, 1967, the Israeli army carried out a counter attack and took over the city and the entire West Bank to the Jordan River. In 1950, the Israeli Parliament proclaimed Jerusalem for the capital city, however, most countries do not accept this status, and state embassies are in Tel Aviv-Jaffa. Today, Jerusalem has about 700,000 inhabitants. The victors and the defeated, they all live together, but still divided sharing a huge level of animosity.

\section{REPRESENTATIVE CASES OF PILGRIMAGE}

When Christian pilgrims go to a pilgrimage and they go to a worship visit to: Church of Mother of God, Holy Temple of the Mother of God in Nazareth and the cave of the Temple in Bethlehem where Jesus Christ was born, , Golgotha and Holy Grave of Jesus Christ; place of the Ascension of Christ on the Mount of Olives, Saint Sion, Saint Mary`s grave in Gethsemane and the tomb of Lazarus in Al-Elzariya and Mount Tabor; the Lake of Tiberias, and the sacred river of Jordan where Jesus Christ was baptized, and they visit other sacred places where you can worship Jesus Christ, the pilgrims become vouchsafe to be called Hajji (Wilkinson, 1977). The oldest testimony of the Serbs pilgrimage was left by Saint Sava, who was first to visit and worship the Holy Grave in 1229, and the second time in 1234. St. Sava went on pilgrimage to the Holy Land by boat from the Budva port, and his pilgrimage lasted for a year. St. Sava was highly respected in the Holy Land (Mirković et al., 1995). This feeling is especially evident in the Holy Sacred Monastery in the Judean Desert. In this Monastery St. Sava received the icon of the Mother of God and the sacred shepard's crook. Serbian monks stayed in this monastery for 150 years. After his second pilgrimage, St. Sava passed away in Velika Trnova in 1236 (Milanović et al., 1995). Orthodoxy and Roman Catholicism 
agree on the name, which is, Holy Land - and in Holy Land there is Jerusalem, a witness where Judaism, Christianity and Islam meet each others through ages. In the area of Holy Land, are located the remains of many civilizations: Jewish, Babylonian, Egyptian, Greek, Hellenistic, Roman, Byzantine, Islamic. On the eve of the Orthodox Easter in the holy city of Jerusalem, about 50,000 pilgrims, Orthodox Christians: Greeks, Russians, Serbs, Romanians, Syrians, Palestinians, Egyptians come to the holy city of Jerusalem. The Church of the Holy Sepulcher represents the most sacred Christian place because it is located at the place where Jesus Christ was crucified, where he died, where he was buried, and where he resurrected on the third day according to the Bible. The temple represents a complex in which there are about 40 altars: Greek, Roman Catholic, Armenian, Coptic. Below the vault of the Church of the Holy Sepulcher are: Greek Orthodox Monastery of Virgin Mary, Greek Orthodox shrine of St. James, Greek Orthodox shrine of St. John, Chapel of the Forty Martyrs, Greek Orthodox Monastery dedicated to Abram, Armenian Chapel of St. John the Evangelist, Ethiopian Chapel of St. Michael, Greek Orthodox Holy Mary of Egypt. On the right side on the entrance in the Temple there is a stairway that leads to Golgotha (the hill of the skull) where Christ was crucified on Good Friday (Hoade, 1971). In the architectural sight the Golgotha shrine is $11.45 \times 9.25$ meters on 4.5 meters above the basilica, which are divided in to two ships. The rock in which the Cross for Jesus Christ crucifixion was stuck makes up one third of this space and it is totally covered - today glazed (plexiglass). Golgotha was named after King and High Priest Salim Melchizedek found the skull of the forefather Adam in the city of Afule in Israel, and buried it here at the foothill of the Golgotha Rock. The blood of crucified Christ, shed on rock and on the skull of forefather Adam, and on that place today is a shrine dedicated to Adam. On the frescoes in churches and monasteries, at the footsteps of crucified Christ there is usually illustrated the skull of forefather Adam. On the Golgotha there is a Roman Catholic chapel (Chapel of Crucifixion) (located at the place where Christ was nailed on the Cross), and the small Greek shrine ( on the place where Jesus Christ died). On the Golgotha there is a Roman Catholic chapel of the Virgin Mary. At the very entrance at the Church of the Holy Sepulcher, there is an anointing plate where Jesus Christ was anointed before he was laid down in the tomb. Today that's a stone of beautiful purple color. It belongs to Greeks, Latinas, Armenians and Copts. Above the anointing plate there are cressets and 8 lamps. In a front of anointing plate there is a place called the Center of the World (Nastić, 1997). A small circular stone slab, surrounded by an iron grid, represents the place where the Virgin Mary and Mary Magdalene attended the crucifixion of Jesus Christ. This holy place belongs to the Armenians. The entrance in the Aedicula - Holy Grave of Jesus Christ, it represents the lobby of the Angel. The Aedicula length is 8.30 meters; same width and height-5.90 meters. Aedicula is the smallest diocese in the world.
The lobby of the Angel is in the front of the Holy Grave of Christ, which enters through a low entrance 1,33 meters high in the stone vault. The Christians enter on this door by kneeling through. The Holy Grave of Jesus Christ is the Church with length of $2.07 \mathrm{~m}$, and $1.93 \mathrm{~m}$ wide. On the right side there is Christ's Grave, a white marble platter of 2,02 m long and 0,93 meter wide. Greek monks who are called Tafos or guards of Christ's Grave are allowed to let three devotees per once to approach (Gilbert, 1985). From 335 AD till today in the Church of the Holy Sepulcher in Jerusalem, pilgrims are becoming witnesses of one of the greatest miracles on this world, the Holy Fire. According to belief Holy Fire testifies the presence of God that enlighten a human. The pilgrims are awake all night on Good Friday. They wait patiently in long lines on the streets of the old city of Jerusalem. The most persistent stay on their feet more than 20 hours. The bluish-whitish flame of the Holy Fire, in a mysterious way, descends into the Church of the Holy Sepulcher where Christ's Grave is located. After the prayer of the Orthodox Patriarch of Jerusalem there is a prescribed procedure based on the provisions of the Law passed by the Ottoman government in 1852. established by Porta for various Christian communities and the entire complex of the Church of the oly Sepulcher (Gilbert, 1985). On Holy Saturday morning, a special commission composed from the members of all Christian communities, Jewish authorities and the Muslim family of Kavas Seljuk Turks) who have been guarding the Holy Grave for 250 years. Kavas wear a fes and tally (TF) - Tafos guardian of the Holy Grave. On the Holy Saturday, around 1 pm., the Patriarch of Jerusalem comes with the other Church's dignitaries and walks around Aedicula three times by singing the Eastern troparion. All lights, candles and cressets are off in the entire Church. The Church of Christ's Grave was previously sealed with a seal of wax and honey. Before the Patriarch unseal the entrance to Christ's Grave; representatives of the Jewish authorities and the police thoroughly search the Patriarch to make sure that he doesn't hide a match or a lighter somewhere. The Patriarch, together with the Armenian dignitary priest, unseal the Church of Christ`s Grave and approaches to Holy Grave of Christ. Patriarch of Jerusalem knees to pray, reading special prayers on behalf of all Orthodox prayers, he prays to Jesus Christ to send them a Holy Fire as the testimony of His resurrection (Milinković, 1998). While Patriarch is praying, in the whole Temple with the greatest devotion, 10,000 prayers are praying with him, all together in one Church. Everyone on his own language brings prayers to the Lord. Believers hold their bouquets of 33 candles and wait for the descent of Holy Fire. Holy Fire first descends on the candles of the Patriarch of Jerusalem, who, first of all, lights up the creeset located inside of glass to keep and protect the Holy Fire from the intentional or unintentional negligence. Then, the Patriarch leaves the church with candles lit up. His appearance induce the enthusiasm of the faithful. A lot of people start to cry out of excitement. The Arabs and Christians hit the table with 
hands and yell "Christ is Risen!", "Trule, He is Risen!". The flame from the Holy Fire has been quickly transferred from candle to candle, so that all blessed people in church in a few minutes will light up their bouquets of candles with the flame from the Holy Fire. At first couple minutes, the Holy Fire burns with a flame that that doesn't sear. This miracle of the Holy Fire occurs only when the Orthodox Patriarch enters the Church of the Holy Sepulcher. Some examples from the past testify that this Orthodox right was threatened. The best example of threat is when the Armenian monophyses paid with money, sultan Murat IV to entrust them to conjure instead of Orthodox Christian the Holy Fire in 1549. It was at the time of the true Patriarch of Jerusalem's Sophrony the Second. At that time the Armenian Patriarch entered in to the Church of Holy Grave and unsuccessfully conjure the descent of Holy Fire. During that time, Orthodox Patriarch Sophronia was outside the Church, next to the pillar, which at one point cracked lengthwise, and from the cracked pillar, the Holy Fire appeared, igniting the candle held by the Patriarch. This pillar can still be seen on the left side entrance of the Church of the Holy Sepulcher (Popović, 2011).

\section{CONCLUSION}

The cultural and geographical determinants of Jerusalem unambiguously point to his supranational identity. Throughout history, Jerusalem has constructed an original and unique cultural pattern. From this universal cultural aspect, Jerusalem is close to all people, ethnic and religious communities. In this cultural universe, cultural-geographical determinants point to the significance of Jerusalem for Serbs and their cultural and spiritual identity. This identity is reflected in the transcendental reflection of God's existence in Jerusalem and the belief of Orthodox Serbs whose attachment to Jerusalem is attributed to Saint Sava who was highly respected in the Holy Land. The meeting of St. Sava with Jerusalem and the Holy Land represents not only his personal but also literary and cultural approach to ancient area that was not well known to Serbs, except through the teaching of the Bible. Jerusalem was and remains a place of worship for members of all three monotheistic religions, and the witness of this is the history that evokes respect. Cultural- geographical determinants point to the religious, military, economic and legal history of this city. The cultural and historical monuments, obviously, with their beauty and symbolism, reinforce the importance of Jerusalem. These places are today the object of cult and legend. Jerusalem is the only city in the world whose history is written in all three sacred books: Bible, Talmud, Quran. The cultural-geographical determination reveals enormous spiritual value, tradition and monumentality of Jerusalem. Jerusalem has an integrative function in modern society. Pilgrimages to Jerusalem are journeys that occupy a central place in the lives of the Jews, Christians and Muslims. The cultural and geographical determinants of Jerusalem point to it`s interculturalism in contemporary world society and contribute to the permeation of cultures and civilizations, the wider values of peace culture among nations and leads to the phenomenon of globalization of general understanding among different nations and religions.

\section{REFERENCES}

Bahat, D. 1980. Carta's istroical Atlas of Jerusalem.Jerusalem: Carta.

Bostoc, H. 1982. The great Ride.Perth: Artlook Books.

Gilbert, R. 1985. Jerusalem the rebirth of City. London: Chatto \& Windus.

Ginsberg, L. 1956. Legends of the Bible, Jewis Publication Societi of Amerika. New York.

Grindea, M. 1980. The image of Jerusalem: A literary chronicle of 3, 000 years. London: Adam International Review.

Hoade, E. 1971. Guide to the Holy Land.Jerusalem: Franciscan Printing Press.

Milinković, I. 1998. Sveti Oganj u Jerusalimu.Niš: Manastir svetog Jovana Krstitelja.

Mirković, K., \& Kalezić, D. 1995. Sveti Sava.Nikšić: Unireks; Beograd: Narodno delo.

Nastić, D. 1997. Jerusalim istorija i vodič. Beograd: Ljiljana Nastić i Dimitrije Nastić.

Peters, F.E. 1985. The Holy city in the eyes of the chroniclers, visitors, pilgrims. Princeton: Princeton legacy Library.

Popović, D. 2011. Koga imam na nebu.Bonart, Nova Pazova.

Wilkinson, J. 1977. Jerusalem Pilgrims. Lincoln, United Kingdom: Aris \& Phillips. 